Research

\title{
Borehole inventory, groundwater potential and water quality studies in Ayede Ekiti, Southwestern Nigeria
}

\author{
Olusegun O. Ige ${ }^{1} \cdot$ Hycent O. Ameh ${ }^{1} \cdot$ Ifeoluwa M. Olaleye $^{1}$
}

Received: 7 September 2020 / Accepted: 5 November 2020

(c) The Author(s) 2021 OPEN

\begin{abstract}
This study aims at determining the state of government provided boreholes, evaluating groundwater potential and quality assessment within the Ayede Ekiti community. 12 Vertical Electrical Soundings (VES) were conducted using Schlumberger array in order to determine geoelectric layers and fracture attributes. Also, 12 water samples were collected from the study area to evaluate physicochemical characteristics of the groundwater. The study revealed average values of total depth of boreholes, static water levels and water column in the boreholes to be $18.77 \mathrm{~m}, 6.77 \mathrm{~m}$ and $11.99 \mathrm{~m}$ respectively. $70 \%$ of the boreholes are either abandoned, damaged or with evidence of corrosion and encrustation. Geophysical investigation revealed weathered layer thickness ranging from 1.3 to $34.7 \mathrm{~m}$ with two regimes of fracture at $40-50$ and $75-80 \mathrm{~m}$. The frequency of curve types obtained shows $16.67 \%, 33.33 \%, 25 \%, 8.33 \%, 8.33 \%$ and $8.33 \%$ for $\mathrm{AK}, \mathrm{HA}, \mathrm{KH}, \mathrm{AA}, \mathrm{QH}$ and $\mathrm{HK}$ respectively while weathered and fractured basement are identified as the two types of aquifer unit. Results of water analysis unveiled that dominance cations are in order $\mathrm{Ca}^{2+}>\mathrm{Na}^{+}>\mathrm{K}^{+}>\mathrm{Mg}^{2+}$ while anions are in the order of $\mathrm{HCO}_{3}{ }^{-}>\mathrm{Cl}^{-}>\mathrm{SO}_{4}{ }^{2-}$. Three types of hydrochemical facies present are $\mathrm{CaHCO}_{3}>\mathrm{NaHCO}_{3}>\mathrm{CaCl}$ in $66.67 \%$, $25 \%$ and $8.33 \%$ respectively. The Wilcox plot suggests the suitability of the groundwater samples for irrigation purposes when compared with the World Health Organization standards. Despite potential for groundwater and good quality of analyzed samples, the problem of water in this community is traceable to inadequacy in exploration, shallow boreholes with consequent seasonal water availability.
\end{abstract}

Keywords Ayede ekiti · Borehole inventory · Geoelectric sounding · Groundwater potential · Water quality

\section{Introduction}

Increase in human population and agricultural activities in rural and urban areas have led to a corresponding over withdrawal of groundwater in order to meet the desired purpose [1]. Global water resources can be classified into two main bodies of salt and fresh with $97.2 \%$ and $2.8 \%$ volume respectively [1]. Hence, borehole water has gained increased importance as it represents the largest portion of water supplies used for different applications [2]. However, the decision to drill a privately owned borehole now sends fears that kill faster than virus because of the fear of failure and luxurious symbol of owning a borehole. In addition, the most relevant borehole-related risks in the area include drying up of wells and deterioration of water quality as a result of unprofessional completion. Despite the policy of Federal government on

Supplementary Information The online version contains supplementary material available at https://doi.org/10.1007/s43832-020-00001 $-\mathrm{z}$.

$\triangle$ Ifeoluwa M. Olaleye, olaleye.im@unilorin.edu.ng; Olusegun O. Ige, vickyige2002@yahoo.com; Hycent O. Ameh, hycentoliver@gmail.com | ${ }^{1}$ Department of Geology and Mineral Sciences, University of Ilorin, P.M.B. 1515, Ilorin, Nigeria.

Discover Water (2021) 1:2 | | https://doi.org/10.1007/s43832-020-00001-z

Published online: 14 January 2021 
provision of water in quantity and quality as contained in the Sustainable Development Goal 6 (SDG 6) by 2020, inadequate information about basic aquifer parameters is inimical to practical implementation of the policy.

Ayede town is a typical basement complex area with proven shortage of water for agricultural and industrial developments. The need for this study was further supported by the suspected cholera outbreak around the town in 2011 [3]. Efforts have been made at several levels of governments, institutions and individuals to solve water shortage and/ or improve the quality. These include the Omikurudu Dam in Ayede, Asijire Dam in Ikun, political constituency water projects. While the dams are abandoned despite the huge volume of water present, the constituency borehole water projects have all failed due to inadequacies in the exploration and exploitation programmes. Consequently, it has subjected the residents to unnecessary stress by trekking for kilometers in search of potable water for domestic use. For mapping shallow subsurface geological structures, aquifer units, types and thickness of aquifers, resistivity method provides good resolution and excellent sensitivity to changes in measuring parameters [4-8]. Implications of the presences of mineral ions, that dissolved from soil particles and rock grains on the quality of groundwater and its suitability for drinking and/ or irrigation purposes have been well discussed $[9,10]$. Their findings revealed anthropogenic and geogenic sources as major contribution to groundwater pollution. There is paucity of information on water potential and quality in the area investigated. However, [11] reported that groundwater of the study area has low concentration of dissolved mineral due limited rock-water interface. Reports of these investigation showed that the water was suitable for both drinking and irrigation purposes when compared with international quality standards. [12] carried out detailed geological mapping and water quality assessment in Ido/Isin area of Ekiti state. This was with a view of identifying and classifying the rock types and their relationship with the water body. Three major water facies were distinguished and it was concluded that the total quality of the groundwater is principally controlled by the chemistry of local geology. Christopher and Olatunji [13] classified Ogbese River on the basis of their quality using Water Quality Index (WQI). It was reported that virtually all the parameters tested are within the maximum permissible limit of national and international standards for both major ions and heavy metals. Bayowa et al. [14] worked on the integration of hydrogeophysical and remote sensing data in the assessment of groundwater potential of the basement complex terrain of Ekiti state, southwestern Nigeria. Local groundwater potential map was generated which shows five distinct groundwater potential zones namely; very low, low, moderate, high and very high, it was however concluded that the groundwater potential of the area is generally of very low to moderate level class.

Thus, an integrated approach was used in the study in order to evaluate the state of government provided boreholes (from constituency projects), determine the potential for groundwater exploitation to alleviate the communal suffering and assess the quality of groundwater within the town.

\section{Location of the study area}

The study area is Ayede town, $8 \mathrm{~km}$ north of the present Oye Local Government Headquarter, which serves as a link between Ekiti and Kwara States in Nigeria. It is bounded by latitudes $7^{\circ} 53^{\prime} \mathrm{N}$ and $7^{\circ} 54^{\prime} \mathrm{N}$ and longitudes $5^{\circ} 19^{\prime} \mathrm{E}$ and $5^{\circ} 20^{\prime} \mathrm{E}$ (Fig. 1). It covers an area of about $20 \mathrm{~km}^{2}$ and easily accessible by road all through the year [11]. The drainage is generally dendritic with hummocky and undulating topography [11]. Annual rainfall is about $1300 \mathrm{~mm}$ and its distribution is bimodal within hydrologic year [11]. The first peak of the rain occurs between June and July while the second peak of the rain is between September and October [10].

\section{Geology and hydrogeology of the study}

The study area is dominated by rocks of Precambrian ages (Fig. 2). According to [15], the rocks include Migmatites and Charnokites. These rocks define the undulating nature of the topography as they appear as low-lying within the town but as inselberg surrounding the entire area [15]. In basement complex area, the type of rock present, topography, their mineralogy and deformation history can contribute significantly to availability of water [16].

Rocks dominated by ferromagnesian minerals such as Charnokite, can disintegrate to clayey unit which might eventually serve as an aquiclude while rocks dominated by quartz grain can breakdown into sandy unit which can serve as an aquifer. The major sources of water in the study areas are the seasonal rainfall, rivers and groundwater. The groundwater is the most prevalent due to the fact that other sources are seasonal and prone to pollution. However, groundwater availability in basement complex terrain is typically a function of overburden thickness of the weathered basement and 


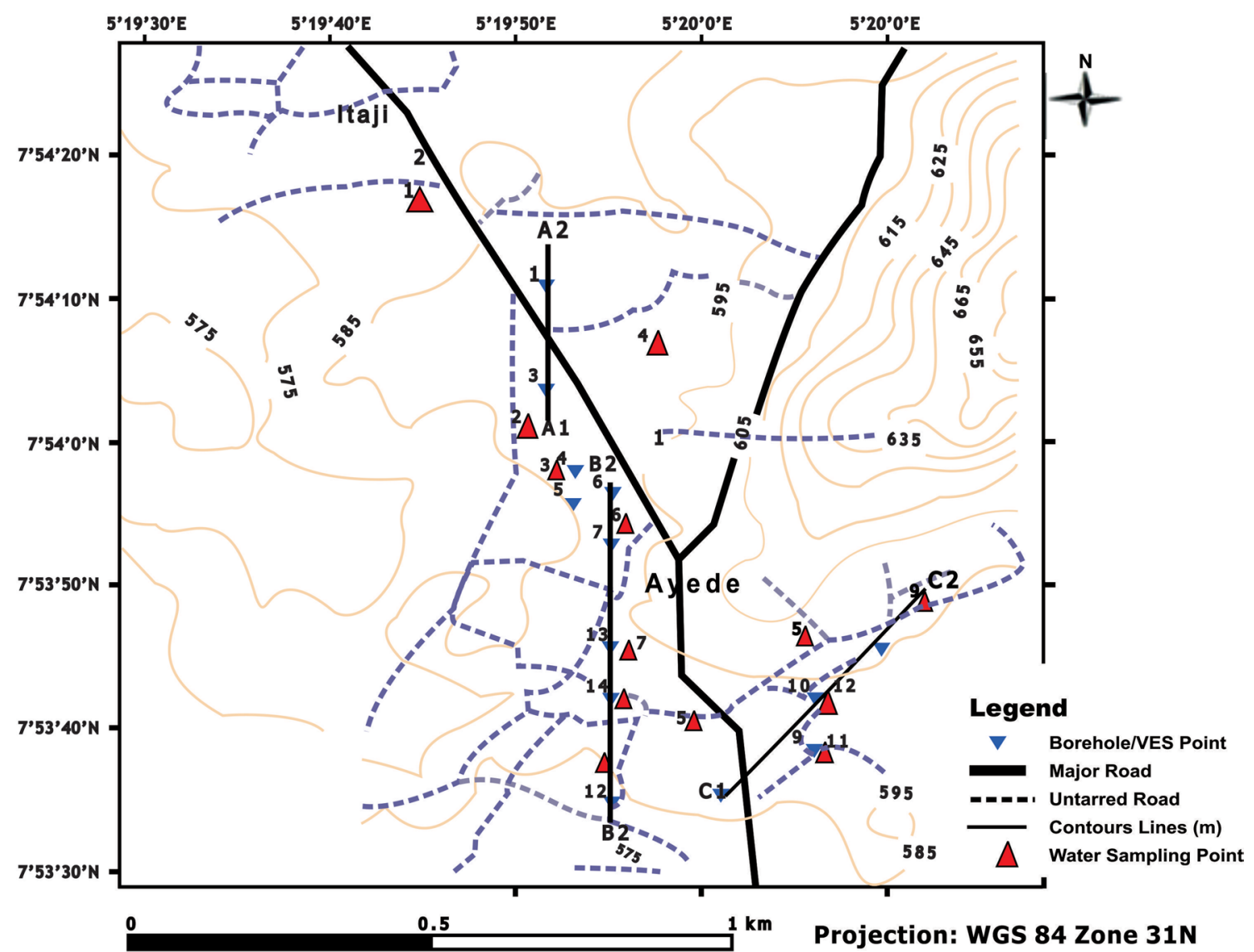

Fig. 1 Topographical map of the study area showing the geo-electric cross sections, boreholes and VES positions

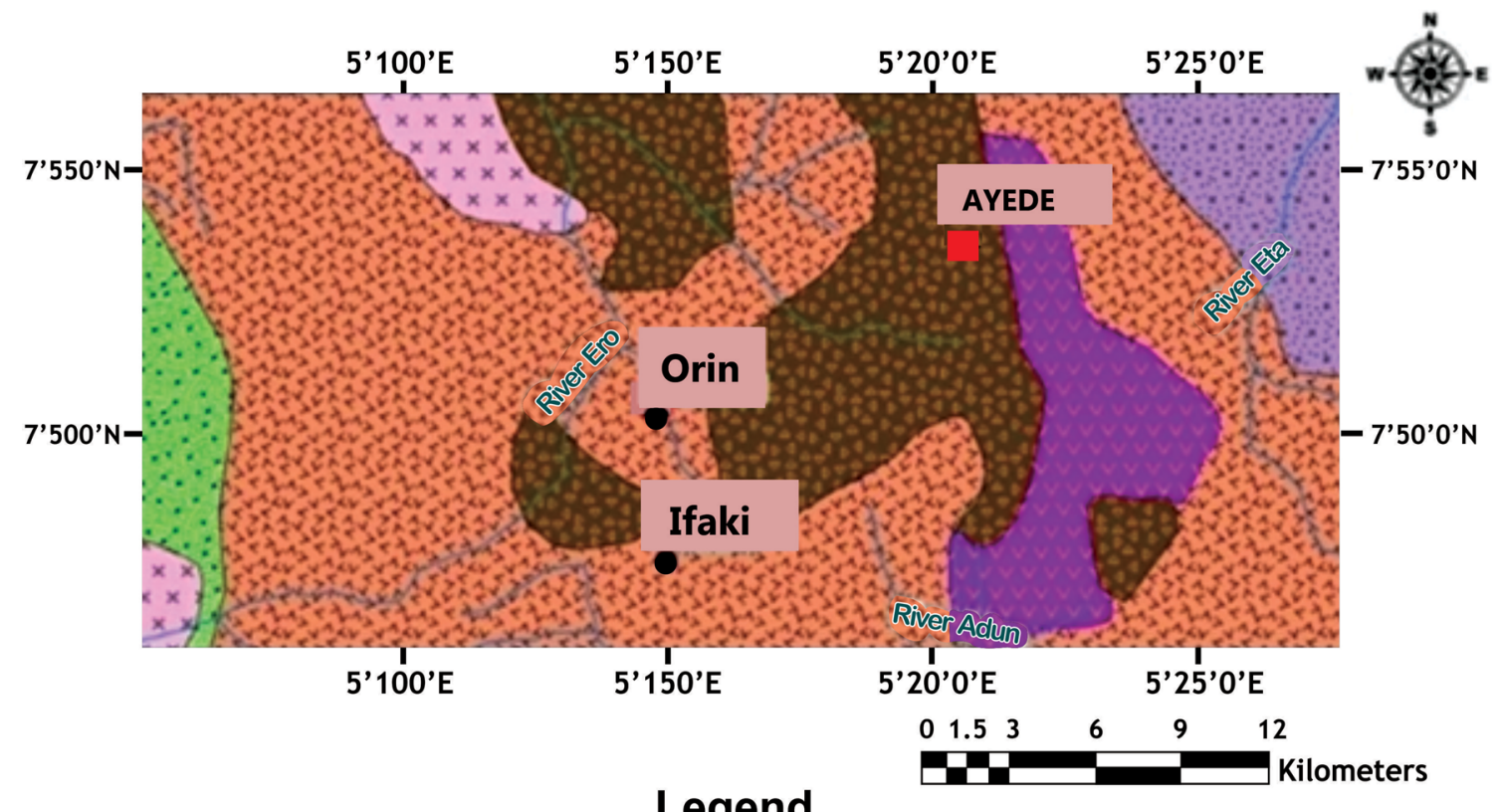

\section{Legend}

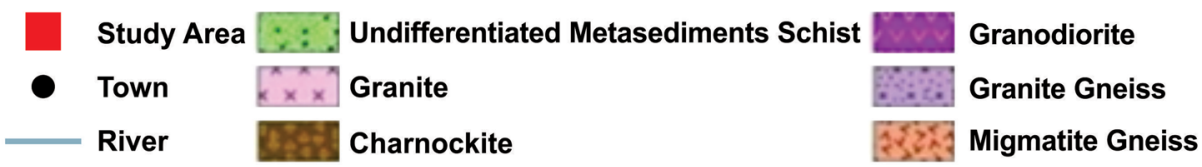

Fig. 2 Geological map of part of Ekiti State showing the study area (Modified from [18]) 
density of fractures [17]. In addition, undulating topography of the area can facilitate and increase run off into shallow wells and surface water bodies thereby encouraging degradation of water quality.

\section{Materials and methods}

\subsection{Borehole evaluation}

Static water level, water column and total depth recovered from drilling were measured using calibrated —end—sensor attached meter tape as shown in Table 1. The tape was quietly lowered until the probe touches the water level which generates that signals the depth to static water level. The probe continues until the final depth is reached. The well type, locations, pump types and depth of installation were also examined for proper document and interpretation (Table 2). The column of water in each borehole was estimated using the difference between the static water levels and the total depths. All the boreholes were fitted with either 0.5 or 0.7 capacity horse power pump.

\subsection{Vertical electrical sounding (VES)}

A total of 12 VES with maximum current electrode spacing (AB) of $300 \mathrm{~m}$ were conducted using Schlumberger array. All the VES points were deliberately located at the existing government provided boreholes in order to examine the true potential of the points for groundwater production. Petrozenith (04) Terrameter was utilized to acquire the VES data following the principle of Ohm's law for current penetration in porous media. The field data was modeled using WinResist computer base software. The results of the interpretation were represented in the form of the resistivity values that can be used for preparing the geoelectric sections. This section reflects vertical variations in resistivity values.

\subsection{Groundwater quality}

Twelve water samples were collected from the 12 boreholes to evaluate physicochemical characteristics of the groundwater. Some of the wells were functional while some have been abandoned (Table 2). The water samples were collected within the water column (at the depth ranging from 5 to $40 \mathrm{~m}$ ) of the boreholes. The samples were collected into new $2 \mathrm{~L}$ plastic bottles rinsed three to four times with the water sample before filling it to capacity and then labelled accordingly and stored at room temperature before laboratory analysis. For collection, preservation and analysis of the samples, the standard method [19] was followed. The $\mathrm{pH}$, the electrical conductivity $\left(\mu \mathrm{s} / \mathrm{cm}\right.$ at $25^{\circ} \mathrm{C}$ ) and the Total Dissolved Solids (TDS) were estimated in the field utilizing a well calibrated Hanna HI9813-6 Portable pH/EC/TDS/Temperature Meter. Subsequently, the samples were analysed in the laboratory for their chemical constituents. Hydrochemical evaluation was assessed using relevant tools such as Gibbs diagram, Stiff diagram, Sodium hazard diagram and Wilcox. RockWare/2006 6.12 and Microsoft Excel Software were utilized to plot the diagrams.

\section{Results and discussions}

\subsection{Borehole inventory}

All information on borehole inventory is compiled in Table 1. Some of these parameters were plotted against the boreholes' locations on Histogram in order to appreciate the behavior of the aquifer. The total borehole evaluated was 12 with four functional while eight were damaged. The total depth of boreholes varies from $5.27 \mathrm{~m}$ (at OSC) to $44.38 \mathrm{~m}$ (AHCl) (Fig. 3a), Static Water Level range from $2.41 \mathrm{~m}$ (at AHC1) to $19.69 \mathrm{~m}$ (77E) (Fig. 3b) while water column range from $0.91 \mathrm{~m}$ (OFS) to $41.64 \mathrm{~m}$ (77E) (Fig. 3c).Well attributes assessments showed that $70 \%$ of the wells are not-functional at the time of study (Table 2). A close observation of the parameters revealed that $60 \%$ of the wells were terminated within the overburden (less than $20 \mathrm{~m}$ ). Consequently, the wells are not only seasonal in production due to effect of evaporation but unfit for any purpose at all seasons due to high degree of turbidity as observed during field study. Also, there is no clear or consistent relationships between any two parameters evaluated. Lack of maintenance also caused high level of encrustation and backfilling as evident in some of the failed holes (Fig. 4). 


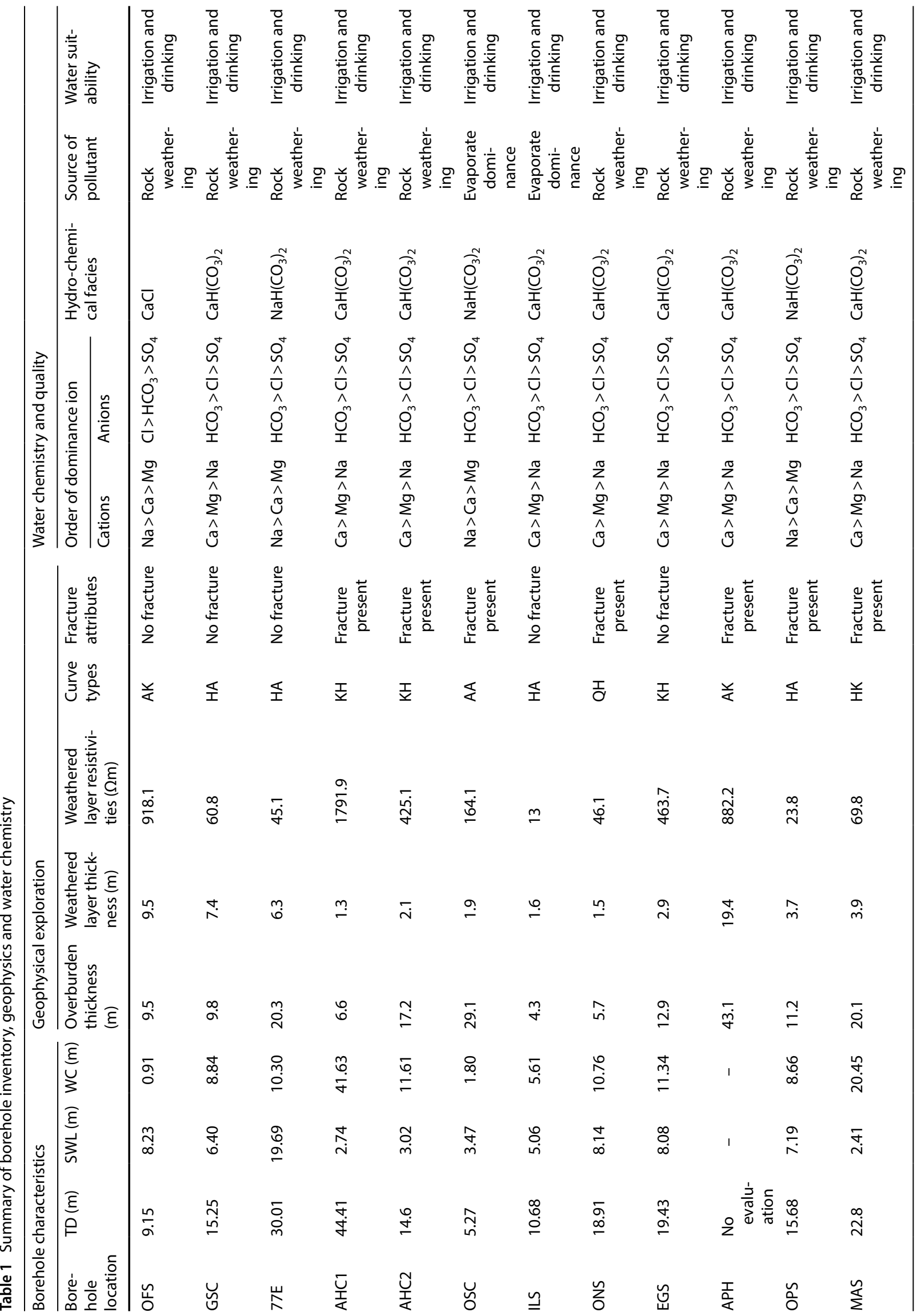




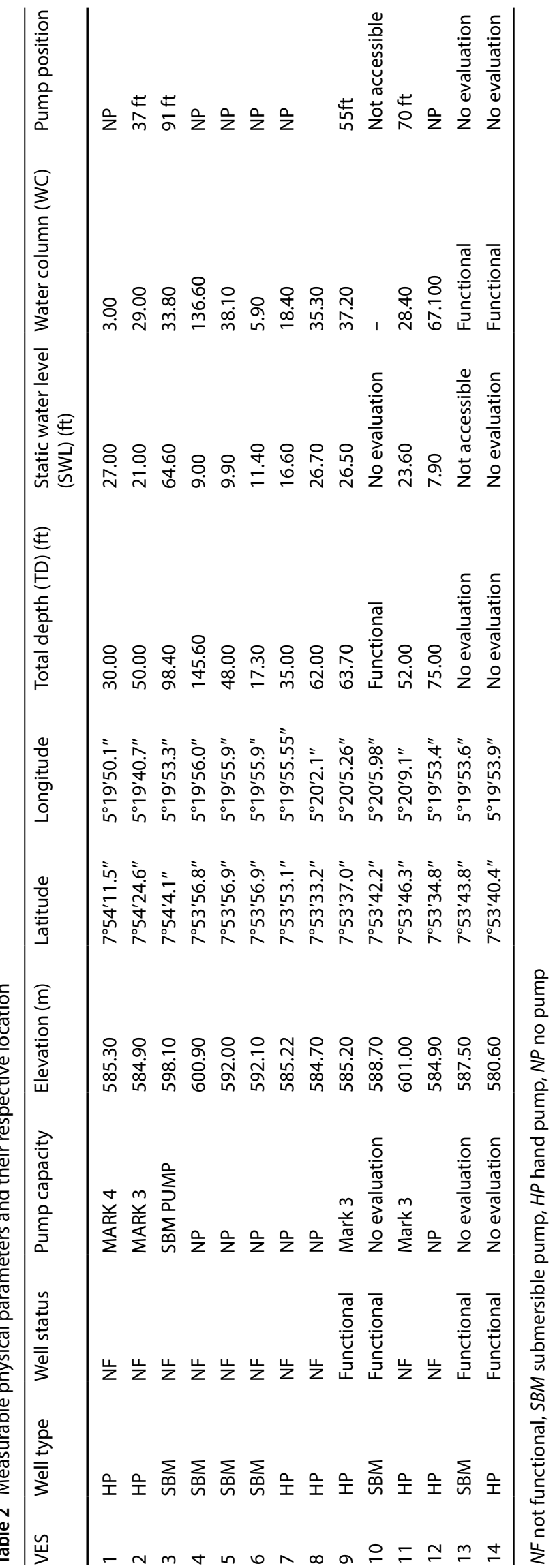




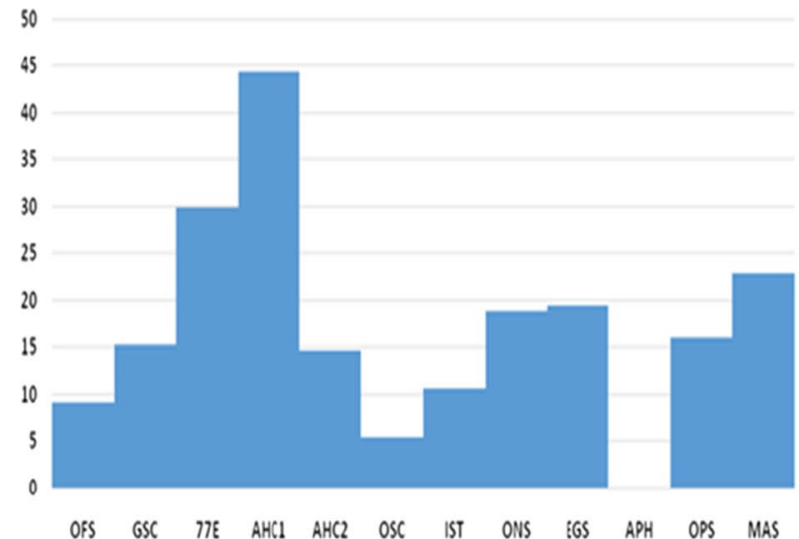

a

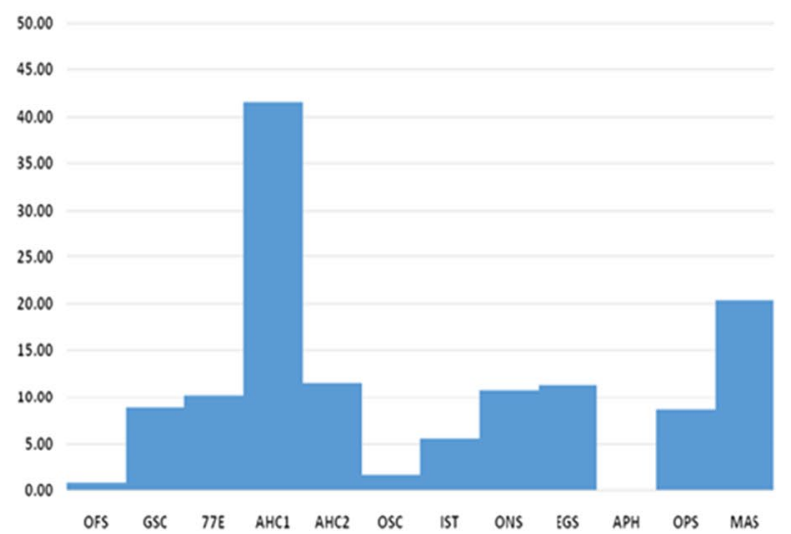

c

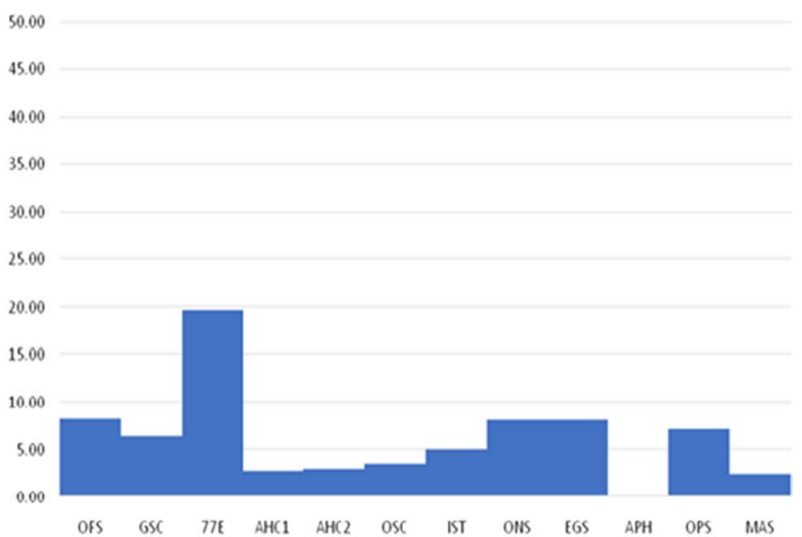

b

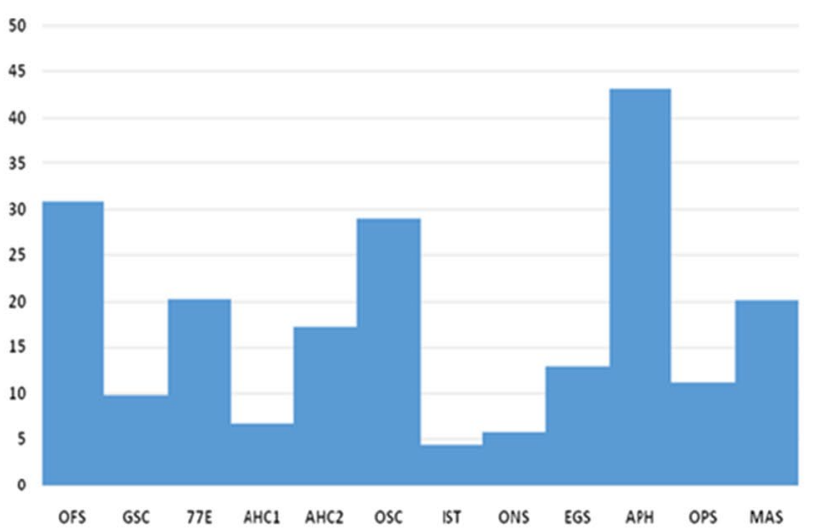

d

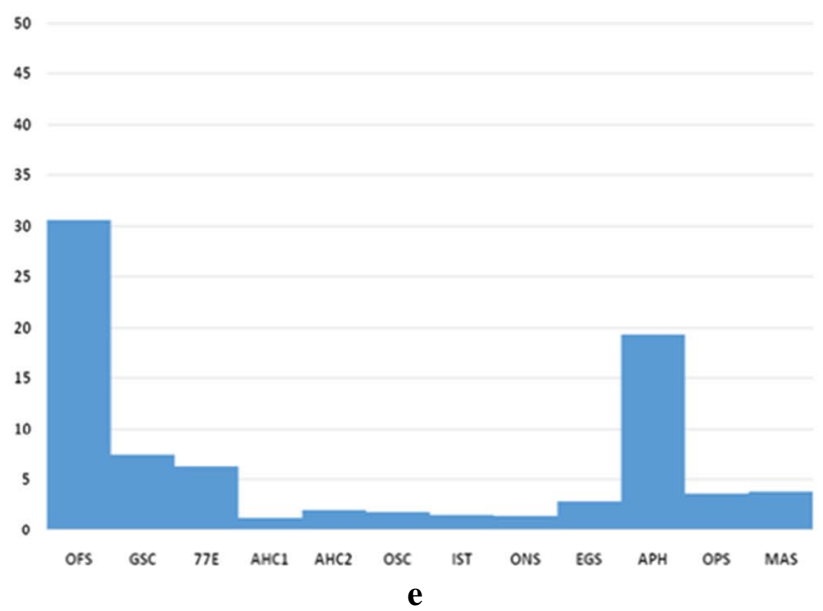

Fig. 3 a Total depth variation $(\mathrm{m})$ vs. location of the boreholes. b Static Water level $(\mathrm{m})$ in the borehole vs. location of the boreholes. $\mathbf{c}$ Water column $(\mathrm{m})$ in the borehole vs. location of the boreholes. $\mathbf{d}$ Overburden thickness $(\mathrm{m})$ vs. location of the boreholes. e Weathered layer thickness $(m)$ vs. location of the boreholes 
Fig. 4 Evidence of corrosion and encrustation at llaro borehole $\left(7^{\circ} 53^{\prime} 53.1^{\prime \prime}, 5^{\circ} 19^{\prime} 55.55^{\prime \prime}\right)$

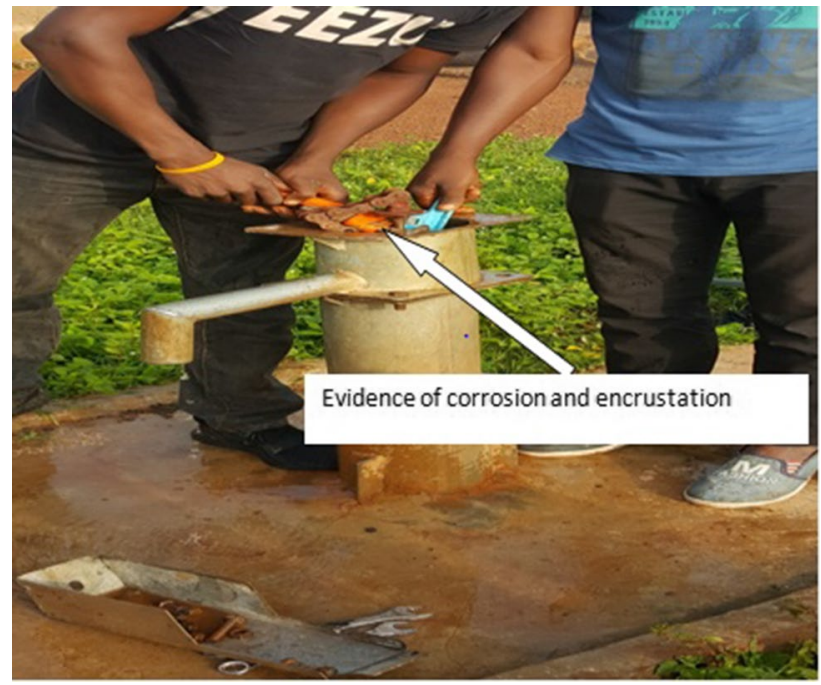

Borehole inventory revealed that the total depth, static water level and water column ranges from (5.25-44.41 $\mathrm{m}$ ), (2.41-19.69 m), and (0.91-41.63) respectively. Also, their averages are $18.77 \mathrm{~m}, 6.77 \mathrm{~m}$ and $11.99 \mathrm{~m}$ respectively. Many of the abandoned boreholes in the area were traceable to: inadequate knowledge of underground geomaterial, Improper well development, improper installation, Lack of maintenance and excessive constant withdraw of water beyond the boreholes sustainable yield. Encrustation and backfilling were evident in some of the failed holes; in boreholes where these processes were prevalent, geophysical results were interpreted to confirm that some borehole were terminated within the overburden thickness $(<20 \mathrm{~m})$.

\section{Potential for groundwater}

The VES positions were arranged such that 3 major alignments (N-S and NE-SW) were assumed (Fig. 5). The 1-D electrostratigraphic generated units revealed four geoelectric layers consisting of topsoil, weathered layer, partly weathered/ fractured basement and the presumably fresh bedrock. The topsoil is relatively thin ( 0.3 and $1.3 \mathrm{~m})$ while the resistivity values range from 22.3 to $154.7 \Omega \mathrm{m}$. This thin vertical thickness is an indication of low potential for water holding capacity especially in the dry season due to increased radiation and evaporation activities. This layer spreads through the entire community and serves as water bearing unit for hand-dug wells especially where is thickest and in wet season. The lateritic clay component of this unit, which marks the contact with the weathered layer, has good water retention capacity but limited flow potential due to non-interconnectivity of the pores. This layer is directly underlain by weathered layer whose thickness range from 1.3 to $34.7 \mathrm{~m}$ and resistivity values range from 13 to $791.9 \Omega \mathrm{m}$. This layer is common in basement complex areas and characterized by moderate to highly weathered lithology. They serve as pathway or conduit for percolating water. In the study area, hand-dug wells that penetrate this layer provide water all year round (personal communication) possibly due to relatively higher interconnectivity of pores and distance from effect of radiation. The observed relatively high values of resistivity compare to the top layer may be due to incomplete weathering and consequent large crystal of grains or pebbles. Also, wide variation in the thickness of the layer may have influenced the variability in the availability of water in the borehole since most boreholes actually depend on recharge from this unit. The third layer is the partially/fractured zone (Table 3), the layer is characterized by uneven thickness range (1.3-95.7 m) and resistivity values range (20.9-4385.1 $\Omega \mathrm{m}$ ) which might also support the hydrogeological diversity in the community. This is the most targeted area for groundwater exploitation in typical basement complex area [14]. The last unit is the unfractured/fresh basement rock with undetermined thickness and resistivity values ( $\geq 1500 \Omega \mathrm{m}$ ). This lithologic unit is known to be generally impervious, hence, non-water bearing. Therefore, aquifer setting is generally heterogeneous and anisotropic in the community and groundwater flow and its accumulation can be controlled by topography, weathered mineral types, degree of tectonic deformation and thickness of overburden.

The curve types obtained in the area AK (16.67\%), HA (33.33\%), KH (25\%), AA (8.33\%), QH (8.33\%) and HK (8.33\%) (Fig. 5) while two types of aquifers (weathered and fractured basement) were delineated. HA-curve type is a four-geoelectric layer curve $\left(\rho_{1}>\rho_{2}<\rho_{3}<\rho_{4}\right)$. It is a combination of the minimum and ascending segment. The first elevated 

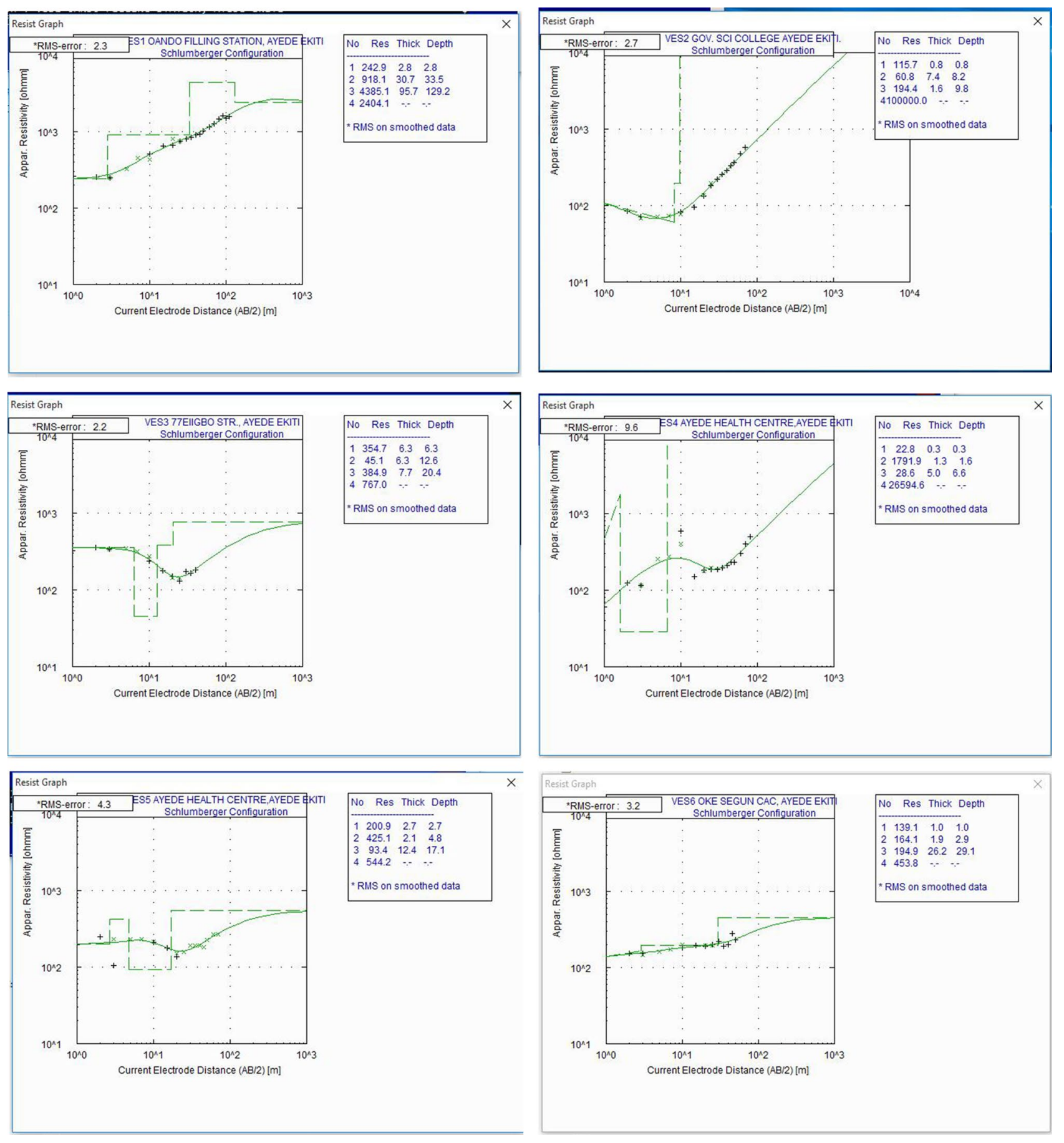

Fig. 5 1-D electrical resistivity models using WINRESIST software

apparent resistivity value $\left(\rho_{1}\right)$ may be associated with effect of dehydration from sun radiation (especially in dry season). The relatively low resistivity values in second and third geoelectric layers, commonly due to presence of pore fluid (water), may have been facilitated by weathered nature of basement rock. Thus, these layers are the major hydrogeologic interest of the curve type. The fourth geoelectric layer has continuous elevated apparent resistivity values with limited water bearing potential. AK-curve type is also a four-geoelectric layer curve $\left(\rho_{1}>\rho_{2}<\rho_{3}>\rho_{4}\right)$. This curve type has consistent elevated apparent resistivity from the first layer until the fourth layer which has low apparent resistivity value. The 

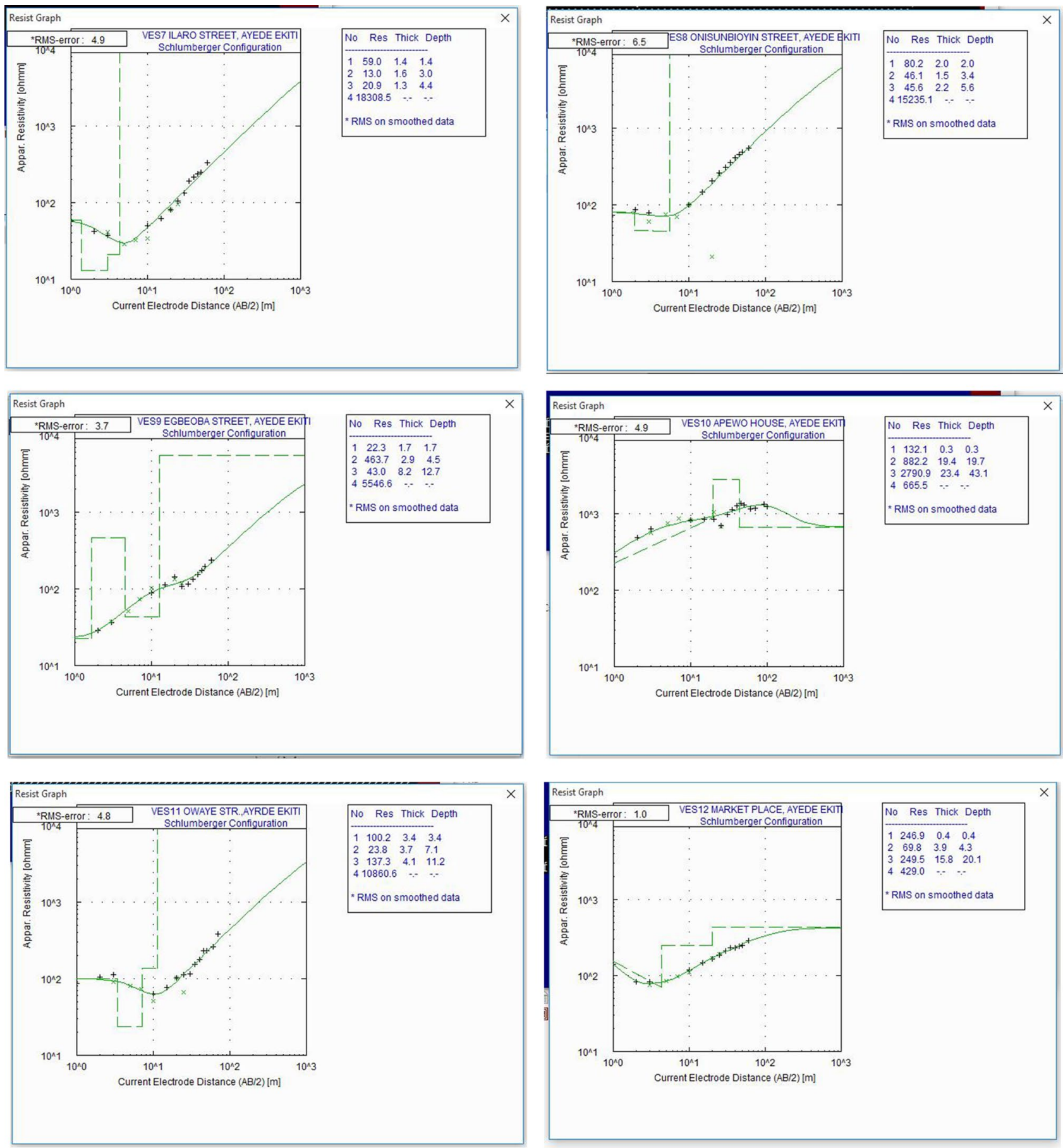

Fig. 5 (continued)

reduced resistivity in the 4th layer signals fracture (porosity) within the fresh basement rock. AK-curve indicates closeness of the basement rock to the surface and the hydrogeologic significance will depend on the presence of water in the fractured fourth layer. $K H$-curve type is another four-geoelectric layer curve $\left(\rho_{1}<\rho_{2}>\rho_{3}<\rho_{4}\right)$. This curve type has two regimes of elevated apparent resistivity values (i.e. the first and fourth layers). Hydrogeologic significance of a KH curve will be determined by low apparent value, degree of weathering and mineral types. The $A A$-curve types are not desired in groundwater exploration. It has consistent elevation in apparent resistivity value $\left(\rho_{1}<\rho_{2}<\rho_{3}<\rho_{4}\right)$ and a consequential limitation for groundwater accumulation or flow. $\mathrm{QH}$-curve type is opposite to "AA"-curve type. It is characterized by consistent reduction in apparent resistivity $\left(\rho_{1}>\rho_{2}>\rho_{3}>\rho_{4}\right)$. This shows that the subsequent geoelectric layer is less 
Table 3 Average thickness resistivity values of major lithologic layer of the study area

\begin{tabular}{lcl}
\hline Thickness $(\mathrm{m})$ & Resistivity $(\Omega \mathrm{m})$ & Description \\
\hline 1.925 & 143.78 & Humus, loose, lateritic clay \\
6.892 & 408.44 & Weathered basement rock \\
16.808 & 512.91 & Partially weathered/fractured zone \\
ND & 6936.05 & Fresh/unweathered basement rock \\
\hline
\end{tabular}

resistive. This type of curve is typical of thick overburden material and desirous in groundwater exploration. However, it requires high level of technicality during drilling to prevent collapse of less resistive lithologies. HK-curve type is a fourgeoelectic layer curve $\left(\rho_{1}>\rho_{2}<\rho_{3}>\rho_{4}\right)$. It has two regimes of low apparent resistivity values (i.e. first and fourth layers) which indicate two aquifer units especially where the fracture in fourth layer is water bearing. This type of curve is one of the most desired four geolectric layer curves in basement complex groundwater exploration.

Two regimes of fracture were observed between the depth of 40-50 $\mathrm{m}$ and $70-80 \mathrm{~m}$. The fractures between the depth of 70-80 m seems to be more pronounced, hence, a total drilling depth of $>90 \mathrm{~m}$ should be considered for sitting a prolific borehole, considering the maximum $A B / 2$ spread of $150 \mathrm{~m}$ and two-third rule of the thumb for actual depth of probing. Generally, the area is slightly weathered and moderately fractured; hence, groundwater potential will depend largely on secondary porosity.

\subsection{Geo-electric sections over the study area}

Three major profiles were identified from the arrangement of the 1-DVES position over the study area. These were used to generate the geo-electric section presented in Fig. 6.

\subsection{Profile A-A'}

The subsurface topography is uneven. Top soils are virtually absent in some VES points but thicker than $3 \mathrm{~m}$ in some places. The apparent resistivity of the top soil ranges from 63 to $285 \Omega \mathrm{m}$ while that of the weathered unit ranges from 39.4 to $1039 \Omega \mathrm{m}$. High fractured unit is absent in VES 1 and 3 but present in VES 4 and 5 with apparent resistivity 31.4 and $106 \Omega \mathrm{m}$ respectively and are expected to be water prolific.

\subsection{Profile B-B'}

The subsurface topography is relatively consistent and uniform except for VES 6 where the lithologies have different morphological characteristics. The thickness of topsoil is generally less than $5 \mathrm{~m}$. The topsoil resistivity ranges from 26.2 to $264 \Omega \mathrm{m}$. Only VES 6 has fractured unit with apparent resistivity $68.8 \Omega \mathrm{m}$. The fresh basement rock whose thickness is known has apparent resistivity range from 329 to $27,527 \Omega \mathrm{m}$.

\subsection{Profile C-C'}

The subsurface topography is undulating with relatively thin topsoil except at VES 9. The rock head slopes NE-SW direction. Apparent resistivity of topsoil range from 52.9 to $3505 \Omega \mathrm{m}$ while weathered layer has apparent resistivity range from 13.9 to $1695 \Omega \mathrm{m}$. The fractured unit has apparent resistivity value range from 22.9 to $223 \Omega \mathrm{m}$ and are expected to be water prolific. The apparent resistivity of the fresh and unfractured basement rock is $>1000 \Omega \mathrm{m}$.

\section{Physico-chemical parameters}

Electrical conductivity is a measure of the ability of a material to conduct electric current [20]. Water enriched with $\mathrm{HCO}_{3}{ }^{-}$and $\mathrm{CO}_{3}{ }^{2-}$ have low conductivity. The value of $\mathrm{EC}$ is an indication of degree of salinity. Low $\mathrm{EC}$ is associated with area of low water-aquifer materials interaction due to high runoff and low infiltration while high EC is linked with area of high discharge water occasioned by long residence time with aquifer materials, high infiltration and impact of anthropogenic activities. The EC is in the range of $40-460 \mu \mathrm{s} / \mathrm{cm}$. According to [21], the groundwater sample is classified as type I 

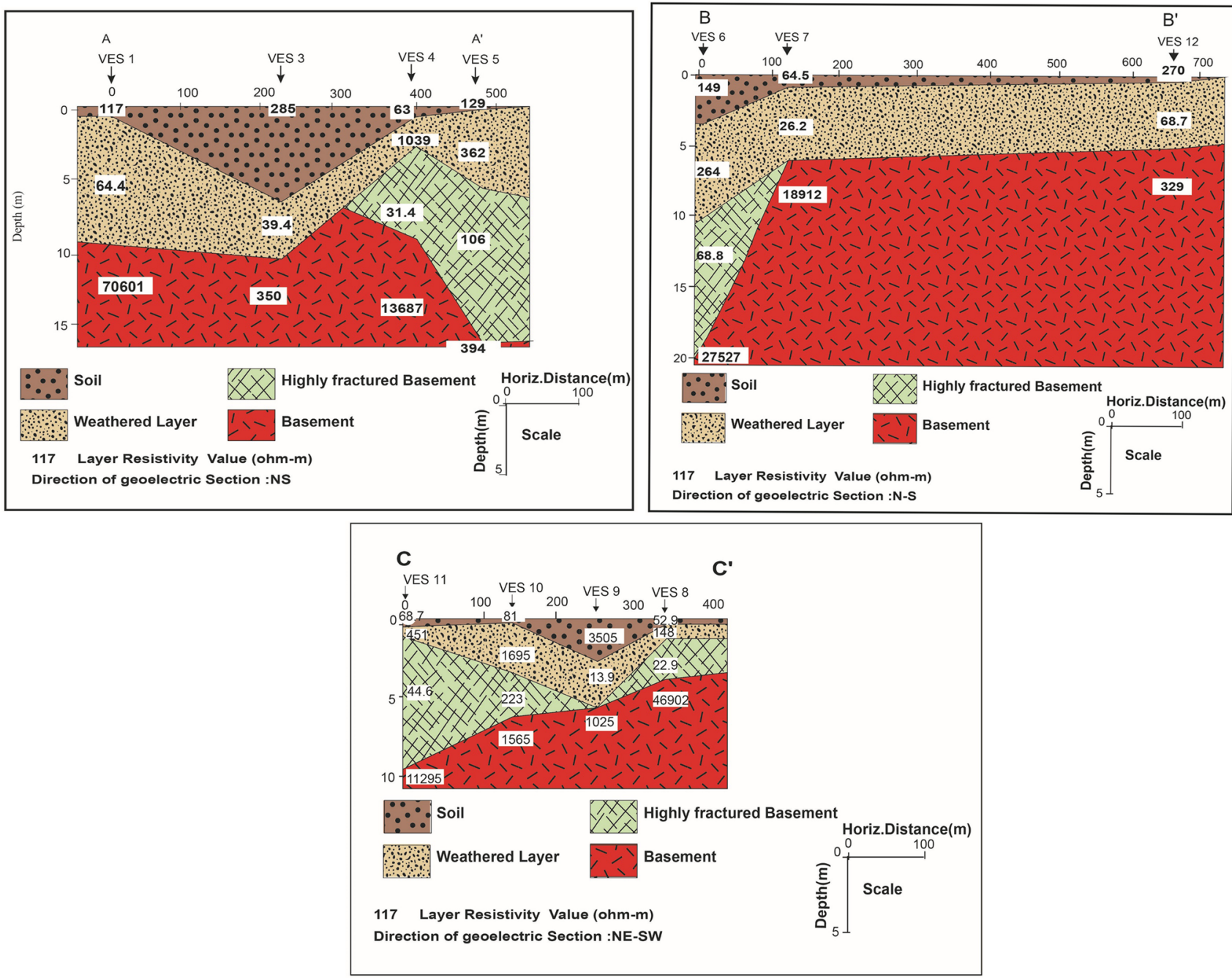

Fig. 6 Geo-electric cross section of three profiles

indicating low enrichment of salts. Total Dissolve Solids (TDS) indicate the total salt concentration of dissolved ions from salts and rocks in water. The amount and classification of dissolved solids depend on the solubility and type of rock where the water is resident [20]. Areas of recharge water at high topographic level have low TDS while discharge areas with low topographic level (anthropogenic contribution) have high TDS. In the study area, TDS values range from 50 to $310 \mathrm{mg} / \mathrm{L}$ which indicate general fresh type of water [22]. EC and TDS have similar triggering factors, thus they are directly related.

Sodium in water is largely dependent on the presence and state of weathering of plagioclase feldspars, nepheline, glaucophane and aegirine [21], especially in basement complex terrain. However, brines, seawater, industrial effluent, municipal waste waters and ion exchange process can also elevate sodium concentration in water. The values range from 0.03 to $20.33 \mathrm{mg} / \mathrm{L}$. Though, the values are generally low and within recommended standard, there is an observed spatial variation in the concentration which signals increase in anthropogenic source over geogenic origin. Potassium in water can be sourced from orthoclase feldspar, nepheline, biotite, leucite and chemical fertilizer [21]. The values of potassium range from 0.04 to $21.05 \mathrm{mg} / \mathrm{L}$. These values are generally less than $\leq 150 \mathrm{mg} / \mathrm{L}$ by World Health Organization (Table 4). This is probably due to high absorption of $\mathrm{K}^{+}$on the clay minerals.

Calcium ions in groundwater are commonly sourced from plagioclase, pyroxene, amphiboles, limestone, dolomite, gypsum, sandstone and shale. The concentration of calcium ranges from 6.4 to $19.45 \mathrm{mg} / \mathrm{L}$ which is very low and normal when compared to standards. Differential impacts of geogenic activities on the groundwater body may be responsible for the spatial variation. Magnesium ion enrichment in groundwater is principally from minerals such as plagioclase, pyroxene, amphiboles and rocks like limestone, dolomite, anhydrite, gypsum, sandstone, ion exchange and presence of 
$\mathrm{CO}_{2}$ in soil zone [23]. Magnesium in the study area ranges from 3.43 to $19.45 \mathrm{mg} / \mathrm{L}$ which indicates values within permissible limit (Table 4).

Chloride $\left(\mathrm{Cl}^{-}\right)$is dissolved from rocks and soils but most prevalent in sewage, brines, seawater, septic tanks. Groundwater receives elevated concentration of chloride when the primary source makes contact with groundwater reservoir. Chloride concentrations range from 3.98 to $45.85 \mathrm{mg} / \mathrm{L}$. The values are within permissible limit and suggesting limited anthropogenic contribution. Bicarbonate $\left(\mathrm{HCO}_{3}{ }^{-}\right)$and Carbonate $\left(\mathrm{CO}_{3}{ }^{2-}\right)$ are principally introduced to groundwater system through dissolved carbon dioxide during precipitation apart from decomposed organic matters. $\mathrm{HCO}_{3}{ }^{-}$vary in concentration from 19.52 to $204.98 \mathrm{mg} / \mathrm{L}$ which suggests soil carbon dioxide $\left(\mathrm{CO}_{2}\right)$ as the source of enrichment. The variability of concentration with the community may be due to prevailing condition of alkalinity.

Sulphate $\left(\mathrm{SO}_{4}{ }^{2-}\right)$ enrichment in water system is largely from rocks containing gypsum, iron sulphides, mine water and industrial wastes. In the study area, the concentration range from 2.00 to $15.00 \mathrm{mg} / \mathrm{L}$ which is generally within the permissible limits for drinking water standard $[24,25]$. The noticed variation in the concentration can be interpreted as a gradual increase in anthropogenic activity.

\section{Water quality assessment}

Chemistry of groundwater is greatly influenced by the interaction of water with rocks and its travel history. During movement of water through porous media, it carries soluble components of the solid rock in their ionic form thereby altering the chemical composition of the natural water. Broadly, two major sources of groundwater pollution have been identified, that is, anthropogenic (includes surface artificial activities such as landfill, industrial waste, agricultural waste, drill chemical, etc.) and rock-water interaction based on residence time.

The hydrochemical facies classification discusses the origin and distribution of groundwater type along the water flow paths. It also provides information on progressive ion enrichment during water residency in the subsurface and extent of rock-water interaction. In order to evaluate the quality of water and their suitability, a trilinear diagram proposed by Piper [26] was adopted. It consists of two triangular fields on either side of a central diamond-shaped polygon. The left side triangle discusses the cations while the right side triangle discusses the anions. The central diamond-shaped polygon represents an overall geochemical attribute of the water body. The percentages of major chemical variables (Table 5) are plotted on the triangles and projected into diamond shape in order to determine the dominant ion types. Genetically, $66.67 \%$ of the water samples come under carbonate hardness or fresh water type $\left(\mathrm{CaHCO}_{3}\right)$. They are characterized by $\mathrm{Ca}^{2+}$ and $\mathrm{Mg}^{2+}$ of $\mathrm{HCO}_{3}{ }^{-}$and $\mathrm{CO}_{3}{ }^{2-}$ over $\mathrm{Na}^{+}$and $\mathrm{K}^{+}$of $\mathrm{Cl}^{-}$and $\mathrm{SO}_{4}{ }^{2-}$, whereas, $25 \%$ of the ground water samples is characterized by $\mathrm{Na}^{+}$of $\mathrm{HCO}_{3}{ }^{-}\left(\mathrm{NaHCO}_{3}\right)$ which show non-carbonate

Table 4 Comparison of findings to recommended standards for drinking water [24, 25]

\begin{tabular}{lllll}
\hline Water composition & Findings of this work & WHO recommended values & $\begin{array}{l}\text { SON recommended } \\
\text { values }\end{array}$ & Implications \\
\hline TDS & $40-310$ & $500-1000 \mathrm{mg} / \mathrm{L}$ & $500 \mathrm{mg} / \mathrm{L}$ & None \\
Total hardness & $32-188$ & 500 & 500 & None \\
Colour & $0-40$ & 15 & 15 & None \\
Electrical conductivity & $70-460$ & $\leq 1000$ & $\leq 1000$ & - \\
Turbidity (JTU) & $0-28.78$ & 5 & 5 & Nausea, can shield bacteria \\
Bicarbonate & $19.52-204.98$ & $120 \mathrm{mg} / \mathrm{L}$ & $150 \mathrm{mg} / \mathrm{L}$ & - \\
Sulphate & $2-15$ & $\leq 250$ & $75 \mathrm{mg} / \mathrm{L}$ & Laxative effect \\
Calcium & $6.4-51.2$ & $75 \mathrm{mg} / \mathrm{L}$ & $50 \mathrm{mg} / \mathrm{L}$ & None \\
Magnesium & $1.14-19.45$ & $50 \mathrm{mg} / \mathrm{L}$ & $200 \mathrm{mg} / \mathrm{L}$ & Heart failure, kidney disease \\
Sodium & $0.05-20.33$ & $200 \mathrm{mg} / \mathrm{L}$ & $12 \mathrm{mg} / \mathrm{l}$ & Heart failure, kidney disease \\
Potassium & $0.05-23.6$ & $12 \mathrm{mg} / \mathrm{L}$ & $250 \mathrm{mg} / \mathrm{L}$ & Hypertension \\
Chloride & $1.99-45.85$ & $200-300 \mathrm{mg} / \mathrm{L}$ & $0.30 \mathrm{mg} / \mathrm{L}$ & None \\
Iron & 0.003 & $0.30 \mathrm{mg} / \mathrm{L}$ & $50 \mathrm{mg} / \mathrm{L}$ & Cancer, interference with \\
Nitrate & $0.2-7.2$ & $50 \mathrm{mg} / \mathrm{L}$ & & vitamin D metabolism \\
& & &
\end{tabular}


alkali. This water class has $\mathrm{Na}^{+}$of $\mathrm{HCO}_{3}{ }^{-}$over which suggests fresh groundwater with enriched $\mathrm{Na}^{+}$possibly from weathered orthoclase feldspar. $8.33 \%$ of the water samples is characterized by $\mathrm{Ca}^{+}$of $\mathrm{Cl}^{-}(\mathrm{CaCl})$ which suggest that the groundwater quality is becoming brackish due to influence of anthropogenic activities such as direct introduction of table salt to wells to kill germs (personal interview) as the strong acids $\left(\mathrm{Cl}^{-}\right)$exceeds the concentration of the weak acid $\left(\mathrm{HCO}_{3}^{-}\right)$(Fig. 7).

Pearson's correlation matrix was employed to show similarity between pair of chemical variables and how one variable can be used to predict another. The analyses show different levels of relationships between cations and anions (Table 6). Positive correlation coefficients $>0.7$ were considered to be strong while those between 0.5 and 0.7 were considered to be moderately correlated [27]. On the other hand, high negative correlation indicate that the chemical variables are well correlated but in opposite direction. From this study, strong correlations were established between seven pairs of chemical variables (Table 6) such as $\mathrm{Na}^{+}$with $\mathrm{Cl}^{-}(0.94), \mathrm{K}^{+}$with $\mathrm{Cl}^{-}(0.94)$, $\mathrm{Mg}^{2+}$ with $\mathrm{HCO}_{3}(0.71)$ while very weak correlation was established between $\mathrm{Na}^{+}$with $\mathrm{HCO}^{-}(0.71)$ and $\mathrm{K}^{+}$and $\mathrm{SO}_{4}^{2}(0.01)$.

\section{Mechanism controlling groundwater quality}

The origin of dissolved ions in groundwater can be understood by Gibbs' diagram [28]. Gibbs proposed two diagrams (one is related to the ratio of cations- $\mathrm{Na}^{+}+\mathrm{K}^{+}: \mathrm{Na}^{+}+\mathrm{K}^{+}+\mathrm{Ca}^{2+}$ and the other is related to the ration of anions- $\mathrm{Cl}^{-}$: $\mathrm{Cl}^{-} \mathrm{HCO}_{3}$, which are plotted against the TDS, such as to understand the mechanisms that control groundwater chemistry with respect to rainfall (precipitation), rock-water interaction and evaporation (Fig. 8). $33.33 \%$ of the samples (MAS, OPS, IST and EGS) have TDS less than $100 \mathrm{mg} / \mathrm{L}$ with dominant $\mathrm{Ca}^{2+}$ and $\mathrm{HCO}_{3}{ }^{-}$over $\mathrm{Na}^{+}$and $\mathrm{Cl}^{-}$thus, fall within the precipitation domain and indicating a meteoric origin. Whereas, a progressive increase in $\mathrm{Na}^{+}$and $\mathrm{Cl}^{-}$over $\mathrm{Ca}^{2+}$ and $\mathrm{HCO}_{3}{ }^{-}$possibly due to anthropogenic addition of table salt or long time rock-water interactions, the value of TDS increases above $100 \mathrm{mg} / \mathrm{L}$. Thus, $66.66 \%$ of the samples are within rock dominance. This means that the original quality of fresh groundwater developed by geogenic activities has been subsequently modified to brackish due to interferences of anthropogenic sources.

\section{Groundwater usability evaluation}

\subsection{Irrigation purpose}

Elevated concentrations of dissolved ions in irrigation water affect plants and agricultural soil physically and chemically by lowering osmotic pressure in the plant cell [21]. This action prevents water from reaching the branches and leaves, thus reducing productivity. Salinity hazard, sodium hazard, percent sodium, residual sodium carbonate, magnesium ratio, Wilcox

Table 5 Percentages of chemical variables in the study area

\begin{tabular}{lllllllllllll}
\hline Sample ID & OFS & GSC & 77E & AHC1 & AHC2 & OSC & IST & ONS & EGS & APH & OPS & MAS \\
\hline $\mathrm{Ca}^{2+}$ & 38.08 & 68.43 & 36.87 & 86.86 & 45.56 & 83.17 & 31.90 & 40.44 & 50.05 & 60.94 & 50.29 & 56.74 \\
$\mathrm{Mg}^{2+}$ & 26.25 & 17.46 & 43.97 & 12.58 & 36.92 & 16.46 & 37.99 & 25.15 & 49.41 & 34.04 & 46.10 & 29.59 \\
$\mathrm{Na}^{+}$ & 22.14 & 8.85 & 11.62 & 23.70 & 14.86 & 0.23 & 0.1329 & 21.12 & 0.14 & 3.20 & 2.21 & 7.92 \\
$\mathrm{~K}^{+}$ & 13.52 & 5.27 & 7.53 & 23.04 & 5.25 & 0.14 & 1.329 & 13.30 & 0.10 & 1.82 & 1.40 & 5.75 \\
$\mathrm{Total}^{2}$ & 100 & 100 & 100 & 100 & 100 & 100 & 100 & 100 & 100 & 100 & 100 & 100 \\
$\mathrm{HCO}_{3}{ }^{-}+\mathrm{CO}_{3}{ }^{2-}$ & 28.67 & 53.88 & 49.51 & 84.28 & 63.07 & 73.28 & 75.36 & 55.93 & 85.53 & 79.23 & 72.50 & 64.14 \\
$\mathrm{Cl}^{-}$ & 67.07 & 38.33 & 44.04 & 7.49 & 33.65 & 19.57 & 18.75 & 39.79 & 9.35 & 13.42 & 18.06 & 28.83 \\
$\mathrm{SO}_{4}{ }^{2-}$ & 4.26 & 7.95 & 6.455 & 8.23 & 3.28 & 7.16 & 5.88 & 4.16 & 5.14 & 7.37 & 9.44 & 7.03 \\
Total $^{-10 t a n}$ & 100 & 100 & 100 & 100 & 100 & 100 & 100 & 100 & 100 & 100 & 100 & 100 \\
\hline
\end{tabular}




\section{Piper Diagram}



Fig. 7 Piper's diagram of groundwater in the study area

plots, Kelly's ratio and permeability index are some of the evaluating tools. However, Wilcox diagram and Magnesium ratio have been used in this study.

Wilcox [29] proposed diagram with respect to a combination of Electrical Conductivity and sodium percent. This combination classifies the diagram into five zones ranging from Excellent to Unsuitable, with increasing salinity hazard for irrigation. The EC varies from 40 to $460 \mu \mathrm{s} / \mathrm{cm}$ and \%Na varies from 0.14 to $22.14 \%$. All the samples fall within the excellent zone (Fig. 9).

Magnesium ratio (MR) was proposed by Szaboles and Darab [30]. Excess of magnesium in soil damages the soil and renders it alkaline. MR is an adverse condition on crop yields which is measured as Magnesium Ratio. It is computed as:

$$
\mathrm{MR}=\frac{\mathrm{Mg}^{2+}}{\mathrm{Ca}^{2+}+\mathrm{Mg}^{2+}} \times 100 .
$$

$M R<50$ indicates suitability of water for irrigation while $M R>50$ suggests non-suitability. The samples have MR range from 12.65 (AHC1) to 54.39 (77E) with $83.33 \%$ having values less than 50 while $16.67 \%$ of the sample fall in the unstable field for irrigation (Table 7). 
Table 6 Correlation matrix of chemical constituents in groundwater of Ayede
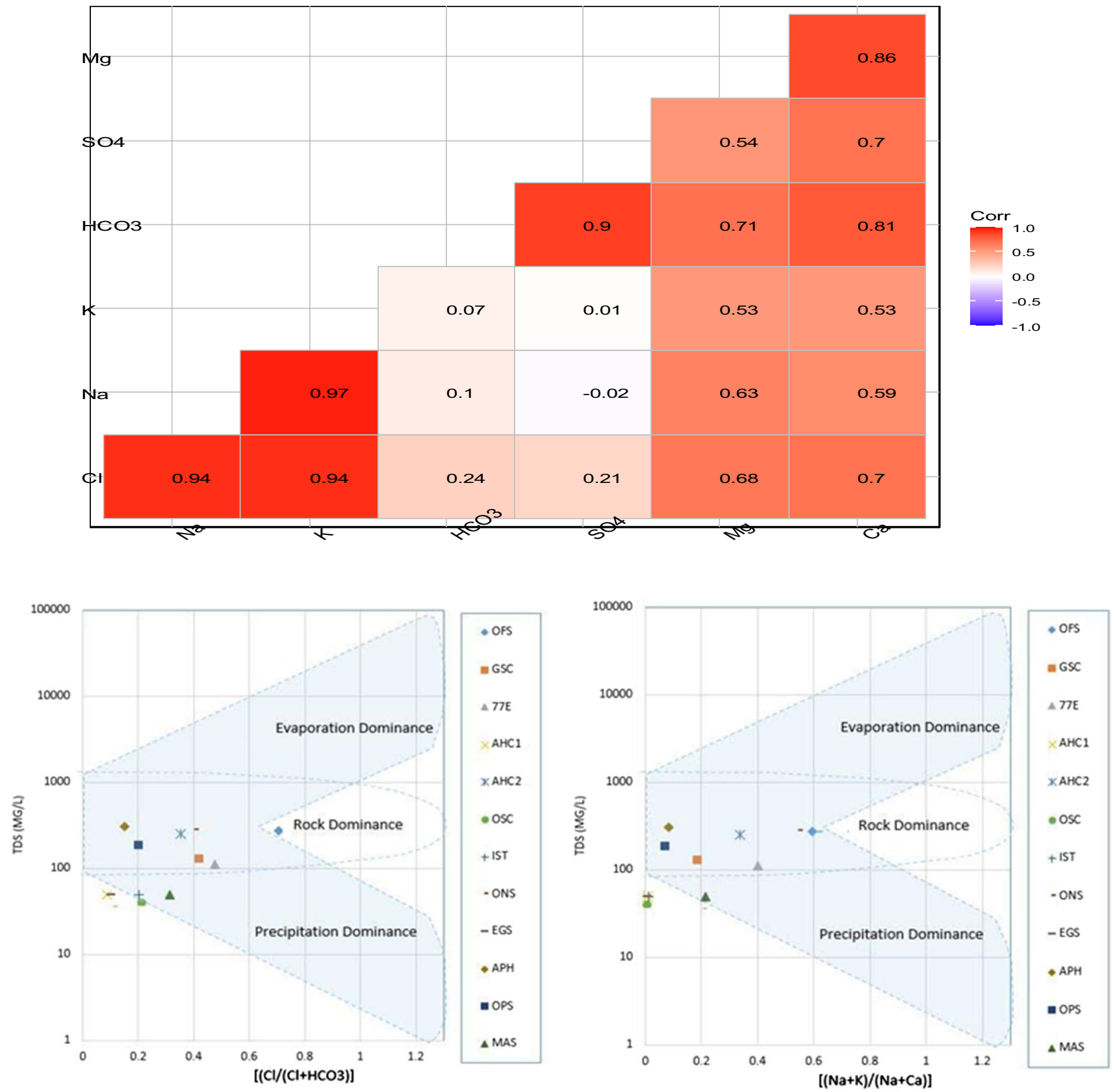

Fig. 8 Position of Ayede Ekiti groundwater in the Gibb's diagram

\section{Stiff pattern}

The Stiff pattern is a polygonal shape created from four parallel horizontal axes extending on either side of a vertical zero axis. According to Stiff [31], the larger the area of the shape, the greater the concentration of the various ions and the greater the degree of pollution. Figure 10a-c shows dominance of $\mathrm{HCO}_{3}$ in all the samples and $\mathrm{Ca}^{2+}$ in $66.66 \%$ of the samples. The increase enrichment of these ions supports rock dominance as the major source of ions. Water obtained from APH borehole appeared to be the most polluted while the least polluted borehole within the community is EGS. The spatial variation in the degree of pollution can be informed by several factors such as geology or mineral type, depth of borehole, resident time, degree of encrustation, access to run-off etc. 
Fig. 9 Position of groundwater samples on Wilcox diagram in the study area
Table 7 Magnesium ratio for groundwater of Ayede

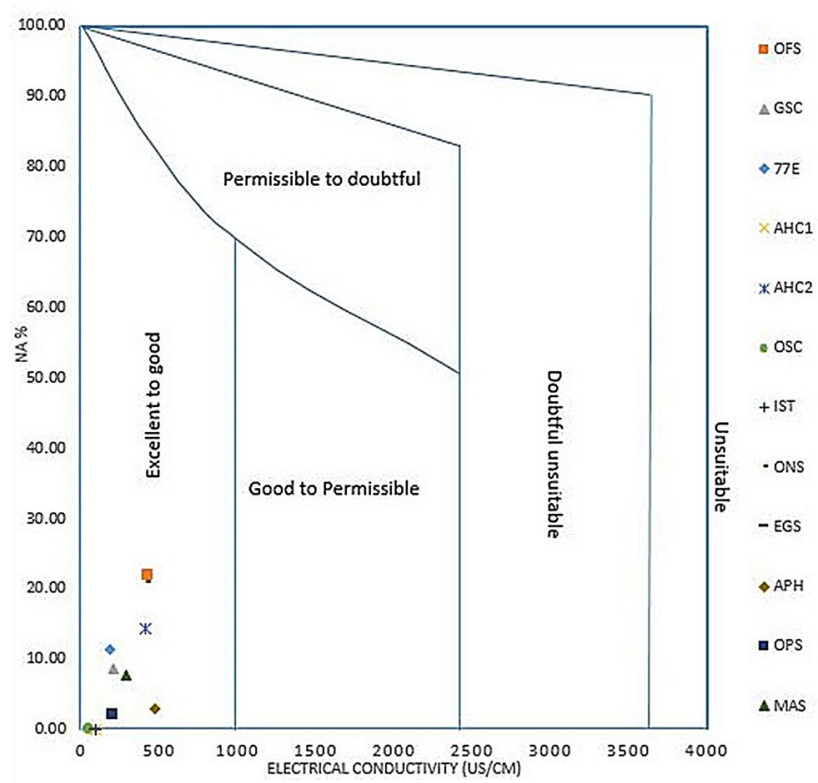

\begin{tabular}{lllllllllllll}
\hline Sample ID & OFS & GSC & 77E & AHC1 & AHC 2 & OSC & IST & ONS & EGS & APH & OPS & MAS \\
\hline MR & 40.85 & 20.36 & 54.39 & 12.65 & 44.76 & 16.52 & 54.36 & 38.34 & 49.83 & 35.86 & 47.83 & 34.28 \\
\hline
\end{tabular}

\section{Conclusion}

The situation of existing boreholes in the study area, potential for groundwater and quality of available samples have been evaluated and discussed in this paper. Borehole inventory revealed that the average total depth and static water level are 18.77 and $6.77 \mathrm{~m}$ respectively while average column of water in the wells is $11.99 \mathrm{~m}$. Investigation showed that many of the abandoned boreholes are linked to inadequate knowledge of subsurface geology before drilling, improper well development and installation, lack of maintenance and drought due to shallow status of the wells. Geophysical evaluation of the area under investigation revealed four geoelectric layers consisting of topsoil, weathered layer, partly weathered/fractured basement and the presumably fresh bedrock was discovered. The frequency of curve types are $16.67 \%, 33.33 \%, 25 \%, 8.33 \%, 8.33 \%$ and $8.33 \%$ for $\mathrm{AK}, \mathrm{HA}, \mathrm{KH}, \mathrm{AA}, \mathrm{QH}$ and $\mathrm{HK}$ respectively two types of aquifers, which are the weathered and fractured basement aquifers were delineated. Two regimes of fracture were observed between the depth of 40-50 m and 70-80 m. The fractures between the depth of 70-80 m seems to be more pronounced, hence, a total drilling depth of $>90 \mathrm{~m}$ should be considered for sitting a prolific borehole. Generally, the area is deeply weathered and moderately fractured, hence, groundwater potential will depend largely on secondary porosity and greater depth.

The results of the water analysis showed that the dominant cations are in order $\mathrm{Ca}^{2+}>\mathrm{Na}^{+}>\mathrm{K}^{+}>\mathrm{Mg}^{2+}$ and anions are in the order of $\mathrm{HCO}_{3}{ }^{-}>\mathrm{Cl}^{-}>\mathrm{SO}_{4}{ }^{2-}$. Three types of hydrochemical facies present are $\mathrm{CaHCO}_{3}>\mathrm{NaHCO}_{3}>\mathrm{CaCl}$ in $66.67 \%$, $25 \%$ and $8.33 \%$ respectively with chemical evolution history of the water being rock weathering. Plot of Wilcox and Magnesium ratios suggest the suitability of the groundwater samples to be fit for irrigation.

However, it is recommended that the estimation of borehole yield be carried out to buffer the current information on aquifer performance. Also, the search for groundwater should be extended beyond $A B / 2$ spread longer than $150 \mathrm{~m}$ (which is the limit of this work) in order to access other possible aquifer units within the subsurface. Seasonal study of groundwater chemistry including information on bacteriological status should also be encouraged. 
Fig. 10 a Position of groundwater samples on Stiff pattern. b Position of groundwater samples on Stiff pattern. c Position of groundwater samples on Stiff pattern

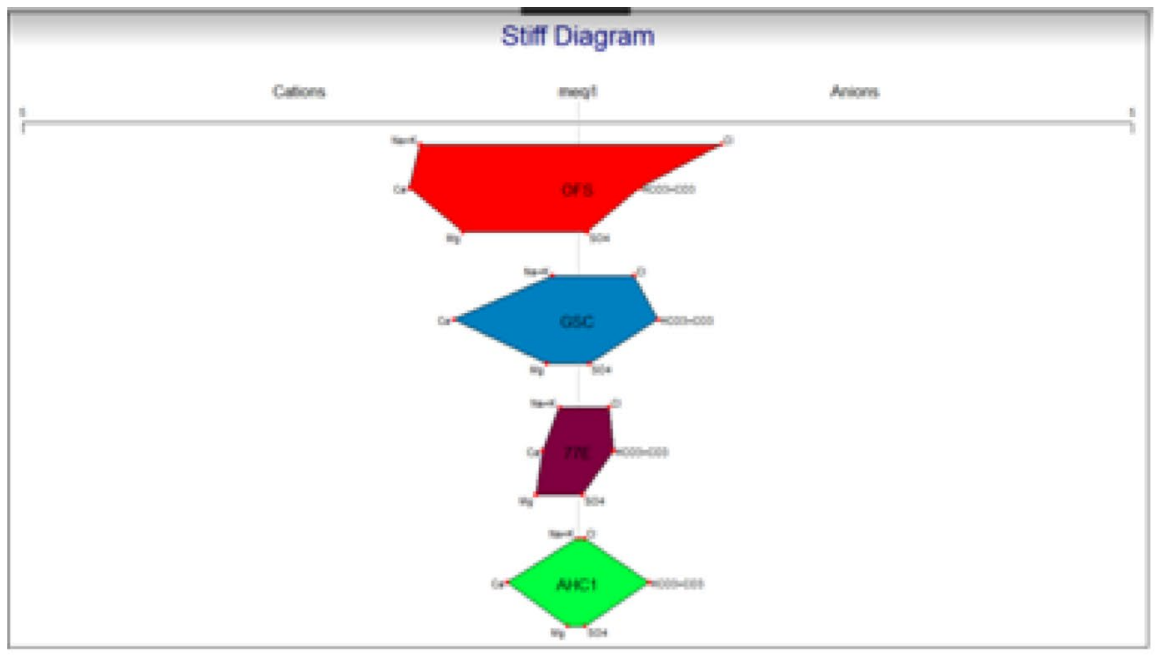

a

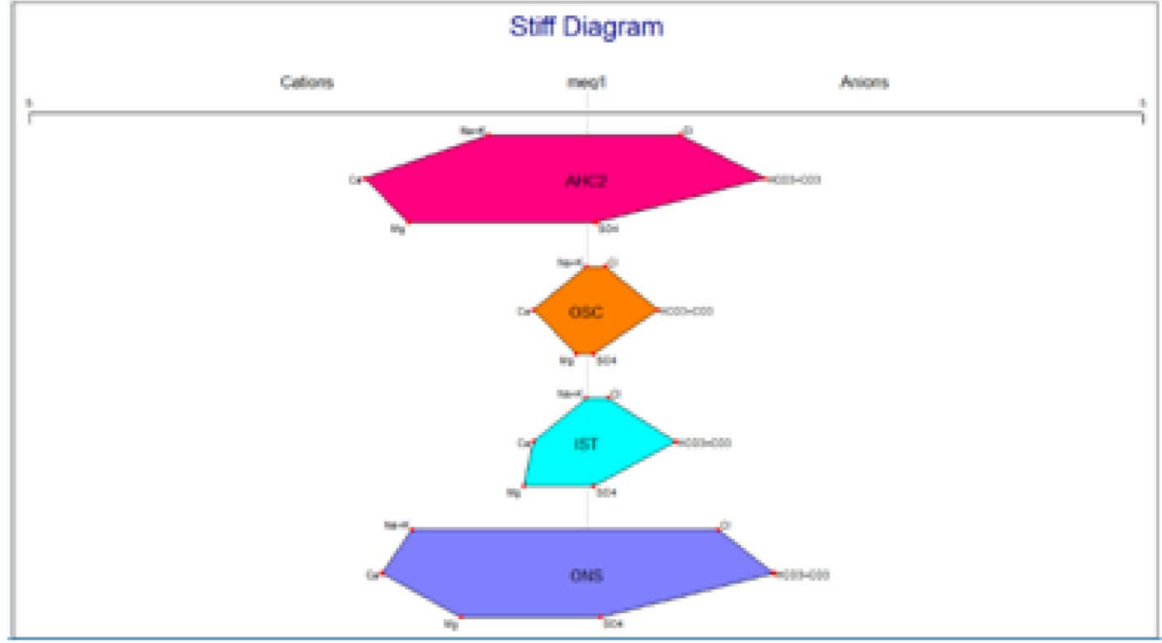

b

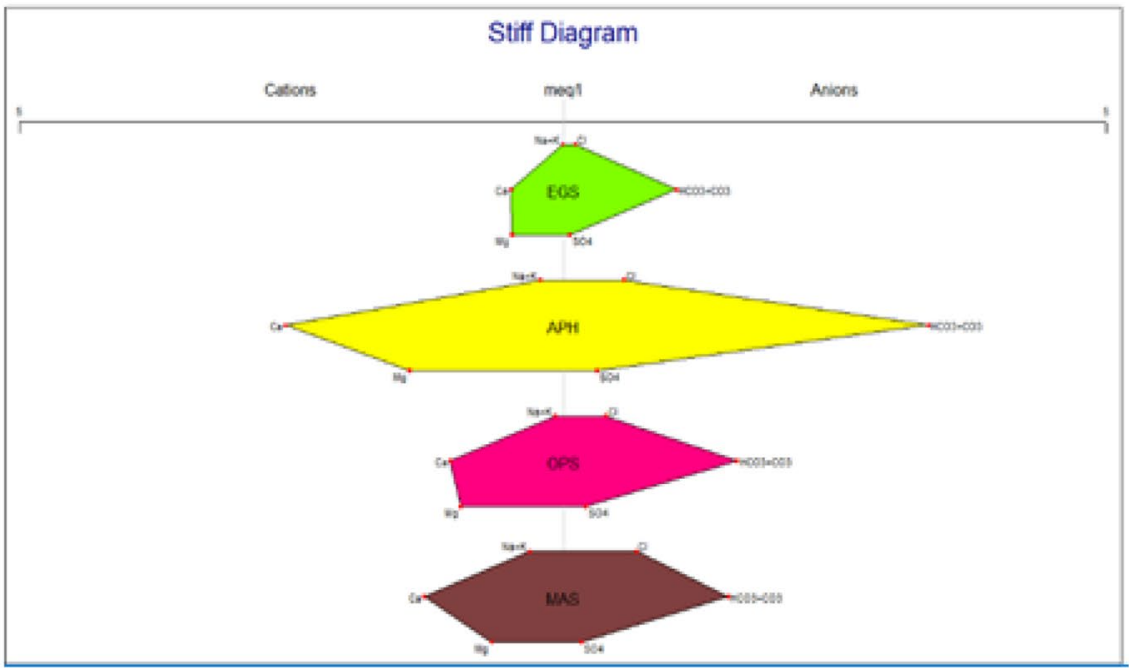

c 
Authors' contributions OOI: conceptualization, methodology, validation, supervision, project administration. HOA: software, formal analysis, investigation. IMO: writing—review and editing, visualization. All authors read and approved the final manuscript.

Data availability statement All data generated and analysed during this study are included in this article and its Supplementary information files.

Competing interests The authors declare that they have no competing interests.

Open Access This article is licensed under a Creative Commons Attribution 4.0 International License, which permits use, sharing, adaptation, distribution and reproduction in any medium or format, as long as you give appropriate credit to the original author(s) and the source, provide a link to the Creative Commons licence, and indicate if changes were made. The images or other third party material in this article are included in the article's Creative Commons licence, unless indicated otherwise in a credit line to the material. If material is not included in the article's Creative Commons licence and your intended use is not permitted by statutory regulation or exceeds the permitted use, you will need to obtain permission directly from the copyright holder. To view a copy of this licence, visit http://creativecommons.org/licenses/by/4.0/.

\section{References}

1. Raghunath HM. Hydrology: principles, analysis, design. 2nd ed. New Delhi: New Age International Ltd Pub.; 2006.

2. Adelana SMA, Macdonald AM. Groundwater research issues in Africa. In: Applied groundwater studies in Africa. London: Taylor and Francis; 2008. https://doi.org/10.1201/9780203889497.ch1.

3. Ige OO, Olasehinde PI. Preliminary assessment of water quality in Ayede Ekiti, southwestern Nigeria. J Geol Min Res. 2011;3(6):147-52.

4. Alabi AA, Popoola OI, Olurin OT, Ogungbe AS, Ogunkoya OA, Okediji SO. Assessment of groundwater potential and quality using geophysical and physicochemical methods in the basement terrain of southwestern Nigeria. Environ Earth Sci. 2020;79:364.

5. Ekwok SE, Akpan AE, Kudamnya EA, Ebong ED. Assessment of groundwater potential using geophysical data: a case study in parts of Cross River State, south-eastern Nigeria. Appl Water Sci. 2020;10:144.

6. Oguama BE, Ibuot JC, Obiora DN, Aka MU. Geophysical investigation of groundwater potential, aquifer parameters, and vulnerability: a case study of Enugu State College of Education (technical). Model Earth Syst Environ. 2019;5:1123-33.

7. Oyeyemi KD, Aizebeokhai AP, Ndambuki JM, Sanuade OA, Olofinnade OM, Adagunodo TA, Olaojo AA, Adeyemi GA. Estimation of aquifer hydraulic parameters from surficial geophysical methods: a case study of Ota, southwestern Nigeria. Earth Environ Sci. 2018;173:1-7.

8. Saana SB, Fosu SA, Sebiawu GE, Jackson N, Karikari T. Assessment of the quality of groundwater for drinking purposes in the Upper West and northern regions of Ghana. SpringerPlus. 2016;5:2001.

9. Kawo NS, Karuppannan S. Groundwater quality assessment using water quality index and GIS technique in Modjo River Basin, Central Ethiopia. J Afr Earth Sci. 2018;147:300-11.

10. Ayoade JO. Evaporation and evapotranspiration in Nigeria. J Trop Geol. 1977;44:9-19.

11. Ige OO, Oredipe IM, Ogunsanwo O. Effect of seasonal variation on physicochemical properties of shallow groundwater in typical basement complex terrain of Nigeria. J Pure Appl Sci. 2015;1:8-17.

12. Ayodele OS. Geology and groundwater quality assessment of IDO/OSI area, southwestern Nigeria. J Environ Earth Sci. 2012;2(5):60-75.

13. Christopher OA, Olatunji O. Quality assessment and classification of Ogbese River using water quality index (WQI) tool. Sustain Water Resourc Manag. 2018. https://doi.org/10.1007/s40899-108-0226-8.

14. Bayowa OG, Olorunfemi MO, Akinluyi TO, Ademulua OL. Integration of hydrogeophysical and remote sensing data in th assessment of groundwater potential of the basement complex terrain of Ekiti State, southwestern Nigeria. Ife J Sci. 2014;16(3):353-63.

15. Rahaman MA. Recent advances in the study of the basement complex of Nigeria. In: Precambrian geology of Nigeria. Geological Survey of Nigeria: Kaduna South; 1988. p. 11-43.

16. Ademilua OL. A geoelectric and geologic evaluation of groundwater potential of Ekiti and Ondo States, southwestern, Nigeria. Unpublished M. Sc. Thesis, Dept. of Geology, Obafemi Awolowo University, lle-Ife, Nigeria; 1997. p. 1-67.

17. Olorunfemi MO, Fasuyi SA. Aquifer types and the geoelectric/hydrogeologic characteristics of part of the central basement terrain of Nigeria (Niger State). J Afr Earth Sci. 1993;16(3):309-17.

18. Eluwole AB, Ademilua OL, Oyinloye A, Adebayo OF, Obasi RA, Talabi AO, Olaolorun OA. Geoelectric assessments of the bauxite ore deposit at Orin-Ekiti, southwestern Nigeria. Int J Appl Environ Sci. 2019;14(2):197-210.

19. APHA. Standard methods for the examination of water and wastewater. 19th ed. Washington DC: American Public Health Association; 1995. p. 1467.

20. Abbasi SA. Water quality sampling and analysis. 2nd ed. New Delhi: Discovering Publishing House; 2016. p. 212.

21. Rao NS. Hydrogeology: problems with solutions. Delhi: Asoke K Ghosh, PHI Learning Private Ltd.; 2017. p. 265.

22. Fetter CW. Applied hydrogeology. 4th ed. Upper Saddle River: Prentice-Hall International; 2001. p. 598.

23. UNESCO/WHO. Water quality surveys: a guide for the collection and interpretation of water quality data. London: UN Educational, Scientific and Cultural Organization; 1978. p. 350.

24. World Health Organization (WHO). Guidelines for drinking-water quality. 4th ed., vol. 13. Geneva: World Health Organization; 2011. p. 541.

25. Standards Organization of Nigeria (SON). Nigerian standard for drinking water quality. NIS. 2007;554:19.

26. Pipers V. A graphic procedure in the geotechnical interpretation of water analysis. Trans Am Geophys Union. 1944;25:914-23.

27. Ebong ED, Akpan AE, Emeka CN, Urang JG. Groundwater quality assessment using geoelectrical and geochemical approaches: case study of Abi Area, southeastern Nigeria. Appl Water Sci. 2017;7:2463-78.

28. Gibbs RJ. Mechanisms controlling world water chemistry. Science. 1970;170:1088-90. 
29. Wilcox LV. The quality of water for irrigation use. US Department of Agriculture, Technical bulletin, vol. 962 , Washington, USA. 1948.

30. Szaboles I, Darab C. The influence of irrigation water of high sodium carbonate content in soils. In: Proceedings of the 8th international congress of ISSS, Trans, II. 1964. p. 803-12.

31. Stiff HA. The interpretation of chemical water analysis by means of patterns. J Petrol Technol. 1951;3:15-7.

Publisher's Note Springer Nature remains neutral with regard to jurisdictional claims in published maps and institutional affiliations. 